\title{
Reflections
}

\section{Discourse in a modern Arctic: can we supplant sovereignty? - commentary to Pawliw, Berthold and Lasserre}

\section{ALEXANDRA CARLETON}

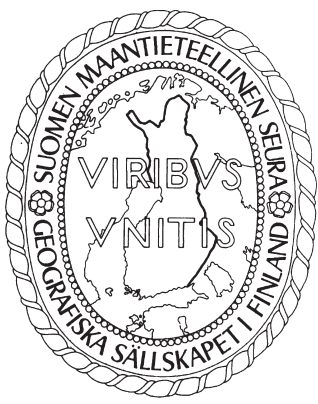

Carleton, A. (2021) Discourse in a modern Arctic: can we supplant sovereignty? - commentary to Pawliw, Berthold and Lasserre. Fennia 199(1) 129-131. https://doi.org/10.11143/fennia.102004

In this reflection I contemplate on the nature of claiming sovereignty over the Arctic through the political discourse, as used in the Harper administration. I question the mobilization of discourses to substantiate claims and lasting jurisdiction over the Arctic as the true nature of reconstructing narratives. In particular, whether the truer questions are how and why we seek sovereignty over areas of wilderness and why discourse is needed at all to legitimise the goodness of such claiming.

Keywords: Pawliw, Franklin, Canadian sovereignty, indigenous, goodness

Alexandra Carleton (https://orcid.org/0000-0002-4857-2986), Independent researcher. E-mail: alexandralcarleton@gmail.com

The article written by Pawliw, Berthold and Lasserre (2021) is an apt discussion of fluctuating attitudes to the Arctic in political discourse, and poignantly highlights that political discourse changes to suit political motivations. On the back of perceived slights, that Canadian sovereignty had been breached in the twentieth century, narratives used during Harper's term in office reasserted Canadian sovereignty over the Arctic, reframing and celebrating Franklin's lost expedition. In the article (Pawliw et al. 2021), discourse is understood as a method of influence (Seignour 2011), to create or rewrite the narrative of Canadian sovereignty. Discourse is evaluated as history, as preservation of cultural sites/ heritage, and also as means of inculcating the notion that unity has always existed between the settler and indigenous populations. This last narrative, the inclusion of the indigenous as valued members of the Canadian identity is the most problematic and, upon reflection, may be seen as a lesson in rewriting socio-cultural dynamics seen throughout the history of indigenous exclusion. Pawliw, Berthold and Lasserre $(2021,13)$ only go so far as to admit that "Canadian claims to the Northwest Passage are constructed on the mobilization of Inuit title", yet the formation of the northern identity - the formation of an identity which may serve politically in the search for Arctic dominance - is anything but indigenous in ontology.

The mobilization of diverse discourses to suit, substantiate and propitiate those who would seek to secure lasting claim and lasting jurisdiction over the Arctic is the true nature of reconstructing narratives and it is a danger. Although Pawliw, Berthold and Lasserre do not suggest that these discourses are flag-bearers to claims that may occur in the future, it is this underlying fact that resonates most soundly. Moreover, the unquestioned assumption that these discourses are allowed or justified resounds of continued coloniality.

URN:NBN:fi:tsv-oa102004

DOI: $10.11143 /$ fennia.102004 (cc) BY
(C) 2021 by the author. This open access article is licensed under a Creative Commons Attribution 4.0 International License. 


\section{Seeking sovereignty over wilderness}

The most important aspect of the piece is that it belies a much more serious question of how we seek sovereignty over areas of wilderness and that, too often, it is done by grand words and gestures speaking of attachment. But is this actual attachment? Of course, there is no true attachment that needs discussion. There is also no true attachment to an entity like the wilds of the Arctic which has, for itself, its own seasons and its own nature unconfined by human interests and indeed, for its existence so far, with very little interest in human confines. Polar wildernesses, for those of us who have lived there at all, have their own tune and she (if we may do her the disservice of anthropomorphising her) pays little regard to our whims and fancies: it is precisely this harsh majestic nature I believe that Amundsen and Nansen revered so much.

Wisdom might suggest that claiming sovereignty over the far reaches of the earth is advantageous for a resources race, in pursuit of humanity's desire to dominate over rather than have dominion for. And perhaps jurisdiction is the best method of preservation. Yet, whether this is the only model for preserving the domains of the wild - and in fact exercising true protective dominion - is another question. In contradistinction lies the Antarctic, which has no national jurisdiction and whose terms of treaty are to come to an end in the near future. What is to be said for these areas of white wild spaces?

\section{Placement of the indigenous}

Yet this truth has little place in discourse which seeks to claim the Arctic. Utilising the voice of sovereignty, and establishing historic bonds (most cleverly by drawing a line of attachment to the indigenous occupation of the area as though to conjure a line of continual historic attachment as used in indigenous claims for autochthony), may almost have been configured by legal counsel. Indeed, "trying to show that Canadians do occupy this territory and that their sovereignty is indeed inherited from past events, here rooted in tragedy and in the old narrative of a Canadian history forged on the fight against nature (Lasserre 1998)" (Pawliw et al. 2021, 10) identifies the discourse to cement the Arctic as part of a broader national consciousness. But this is, even as the authors admit, the formation of a "new Canadian identity" (ibid., 12), thus separating the seeking of a discourse attached to the discovery and exploration of the Arctic coastline from the existent Canadian identity. Indeed, it was during Harper's term that the discourse was pursued. It is, insofar as not actually admitted in the article, a claim potentially fraught with false intention. This may not be seen until many years in the future, demonstrate the actual involvement of indigenous identity, autochthony and ontology and a demonstration of the necessity to preserve and respect the ways of being of this group of people regardless of whether it changes or not.

\section{Seeking a goodness to our Arctic claims}

The primary reflection here is not, however, to once again underscore the need for indigenous inclusion. That would be too easy and presumptuous for someone not of indigenous origin and not involved in politics. My aim here is to question the nature of our seeking and claiming at all. Whether, in the mark of an advanced humanity, our need to claim, dominate, seek (and eventually destroy simply by being there) is indeed a direction to continue pursuing without pausing to think.

Fair to say that States will vie for control over both ends of the earth, with its untapped resources. Again, the discourse matches the money poured into research - engineering, science, fieldwork, tourism, market models, offshore gas reserves - used to recapitulate and legitimate the original discourse for resources and human expansion. The question is to what degree humanity needs to feel better about itself for seeking such expansion. What I mean is this: if we consider it past the point of return that we will inhabit, utilise and develop the vast wilderness of the Arctic (much to many of our chagrin), why is discourse needed at all to legitimise the inherent goodness of such activity?

In much the same way, the discourse to align new Canadian identity with indigenous history may be useful, even necessary to make claiming legitimate. Yet why is there such a need to integrate such discourse with the notion of goodness? In much the same way as Harper's discourse laid claim to 
Franklin himself, and laid claim to the indigenous through including Leona Aglukkaq, Environment Minister and Minister responsible for Parks Canada (Pawliw et al. 2021, 12), the use of positive language such as "hero", "wonderful" and "great" (ibid., 15, 16) speaks of conjuring a goodness which may, or may not be there. In this, I think the language mentioned in the article to be of much deeper (and possibly conjuring) motivation. Indeed, the "use it or lose it" (ibid., 17) admission together with celebration of Franklin's notion of tracing a line through a land so wild (ibid., 17), may point to human desire not to travail the wild sovereign, but to tame it.

The suggestion, at the conclusion of the paper, that Trudeau has moved away from this claiming discourse is intriguing but ultimately cannot change the impact of the previous government.

\section{References}

Pawliw, K., Berthold, E. \& Lasserre, F. (2021) The role of cultural heritage in the geopolitics of the Arctic: the example of Franklin's lost expedition. Fennia 199(1) 9-24. https://dx.doi.org/10.11143/fennia.98496 Seignour, A. (2011) Méthode d'analyse des discours. L'exemple de l'allocution d'un dirigeant d'entreprise publique. Revue Française de Gestion 2(211) 29-45. https://doi.org/10.3166/rfg.211.29-45 